\title{
Características estruturais de milheto sob pastejo rotativo com diferentes períodos de descanso
}

\section{Carlos Eduardo da Silva Pedroso1, Pedro Lima Monks², Otoniel Geter Lauz Ferreira ${ }^{3}$, Otávio Matos Tavares ${ }^{4}$, Lasier Silveira Lima ${ }^{4}$}

\author{
${ }^{1}$ Doutorando, PPGZ, Faculdade de Agronomia, UFPel. \\ 2 PPGZ, Faculdade de Agronomia, UFPel. \\ ${ }^{3}$ Bolsista recém-doutor, PPGZ, Faculdade de Agronomia, UFPel. \\ ${ }^{4}$ Curso de graduação em Agronomia, UFPel.
}

RESUMO - Com o objetivo de determinar o período de descanso (PD) ideal para a pastagem de milheto (Pennisetum glaucum (L.) R.Br.), realizou-se um experimento em delineamento completamente ao acaso, com três períodos de descanso (tempos necessários para expansão completa de 1,5 a 2; 2,5 a 3; ou 3,5 a 4 novas folhas), cada um com quatro repetições de área (potreiros). Foram avaliados o número de folhas vivas/perfilho (NFV), o comprimento final da lâmina (CFL), a relação lâmina/bainha e colmo (L/B+C) e a densidade de perfilhos basilares (DPB) e aéreos (DPA). A maior densidade de perfilhos basais, o maior número de folhas vivas e a maior relação lâmina/bainha+colmo no menor período de descanso determinaram maior participação de lâminas verdes no dossel da pastagem e as melhores características estruturais para produção de forragem.

Palavras-chave: freqüência de desfolha, número de folhas vivas/perfilho, Pennisetum glaucum, perfilhamento, relação folha/colmo

\section{Structural characteristics of pearl millet under rotational grazing with different rest periods}

ABSTRACT - This work used the necessary time (days) for a completely elongation of new leaves, i.e., 1.5-2.0; 2.5-3.0 and 3.5-4.0 new leaves completely elongated in order to determine the rest period (RP) between grazing in Pearl millet (Pennisetum glaucum (L.)R. Br.). The experiment was carried out as a completely randomized design with four replications (paddocks). Evaluations were performed for: number of live leaves/tiller (NAL); final length blade (FLB); blade/sheath and culm ratio $(\mathrm{B} / \mathrm{S}+\mathrm{C})$; basal tiller density $(\mathrm{BTD})$ and aerial tiller density (ATD). The higher BTD; NAL and B/S+C ratio observed in the shortest rest period determined the high quantity of green blades in the pasture sward and consequently the best structural characteristics from the forage point of view.

Key Words: blade/sheath ratio, defoliation frequency, number of alive leaves/tiller, Pennisetum glaucum, tillering

\section{Introdução}

A pastagem de milheto (Pennisetum glaucum (L.) R.Br.) apresenta acentuada produção de forragem, que pode chegar a $20 \mathrm{t} / \mathrm{ha}$ de MS ao longo do seu ciclo de crescimento (Castro, 2002; Ingrid \& Moojen, 2002). Ao mesmo tempo que é uma característica favorável, o hábito de crescimento ereto, associado ao elevado alongamento dos entrenós, confere a pastagem características estruturais indesejáveis, que dificultam o adequado manejo de desfolha desta espécie forrageira. $\mathrm{O}$ milheto apresenta melhor estrutura sob pastejo contínuo quando manejado próximo a $30 \mathrm{~cm}$ de altura em relação ao nível do solo (Castro, 2002; Moojen et al., 1999). Nesta situação, ocorrem elevado perfilhamento basilar e maior relação de folha/colmo, possibilitando ao animal maior densidade de lâminas verdes.

Nesse sentido, a utilização desta espécie sob pastejo rotativo parece um grande desafio, pois, apesar da elevada produção de forragem neste sistema de pastejo (Cauduro et al., 2007), manter essa forrageira em descanso por determinado período pode comprometer a distribuição e o arranjo da sua parte aérea, principalmente, pelo aumento da participação de colmos. Esse evento, além de interferir diretamente na qualidade da dieta ofertada, pela maior quantidade de fibra desse componente vegetal, também pode influenciar indiretamente, dificultando o acesso dos animais às lâminas verdes existentes. Como opção para reduzir este efeito, pode-se determinar como período de descanso o intervalo 
de tempo em que ocorre máximo acúmulo de folhas vivas. No entanto, períodos ainda menores de descanso poderiam gerar características estruturais mais favoráveis do ponto de vista forrageiro, entre elas: a indução de maior perfilhamento, decorrente da menor competição por luz, que resulta em maior densidade de lâminas verdes; o menor número de folhas senescentes pela maior interceptação de luz ao longo do dossel; o menor comprimento de folhas, mais acessíveis ao pastejo; e finalmente a melhor relação folha/colmo e melhor qualidade da forragem disponível, em decorrência do maior controle do alongamento dos entrenós.

Este estudo foi realizado com o objetivo de determinar as modificações nas características estruturais das plantas de milheto utilizadas sob pastejo rotativo em diversos períodos de descanso.

\section{Material e Métodos}

O experimento foi realizado em um período de 143 dias (15/11/2006 a 06/4/2007) na propriedade Rincão do Pedregal ( $\left.31^{\circ} 17^{\prime} 51^{\prime \prime S ~ e ~} 53^{\circ} 00^{\prime} 48^{\prime \prime} \mathrm{W}\right)$, localizada a $28 \mathrm{~km}$ da cidade de Piratini ( $3^{\circ}$ distrito), na região fisiográfica da Serra do Sudeste, Rio Grande do Sul(RS).

O solo é classificado como Argissolo Bruno-acinzentado Ta Alumínico abruptico (Cunha et al., 1998) e foi submetido ao preparo convencional, inicialmente com subsolagem para o rompimento de camadas compactadas na profundidade aproximada de $20 \mathrm{~cm}$ e depois com uma aração e duas gradagens. O solo foi corrigido e adubado de acordo com a recomendação da Sociedade Brasileira de Ciência do Solo (2004). A aplicação de 2,5 t/ha de calcário dolomítico foi feita dia 30/10/2006, enquanto a adubação de base, de $400 \mathrm{~kg} / \mathrm{ha}$ da fórmula 5-20-20, foi realizada a lanço em 14/11/2006. A semeadura do milheto (Pennisetum glaucum (L.) R.Br.) cv. BN2 foi realizada dia 15/11/2006, a lanço (manualmente), em densidade de $35 \mathrm{~kg} / \mathrm{ha}(\mathrm{VC}=100 \%)$. A aplicação de $65 \mathrm{~kg} /$ ha de $\mathrm{N}$ (na forma de uréia) em cobertura foi realizada dia 2/1/2007, após o pastejo de uniformização. A mesma quantidade de nitrogênio foi aplicada aproximadamente 30 dias após a primeira, posterior ao pastejo. Aárea experimental de $8.100 \mathrm{~m}^{2}$ foi subdividida em 12 potreiros de $675 \mathrm{~m}^{2}$. Após o estabelecimento da pastagem, foi feito pastejo de uniformização em 31/12 para reduzir a altura média de $60 \mathrm{~cm}$ para $30 \mathrm{~cm}$ acima do solo em todos os potreiros. Foram utilizadas dez novilhas de corte por potreiro com idade entre 2 e 3 anos (carga de 2.764,41 kg) para o processo de desfolha, que durou de 1 a 2 dias por potreiro. Entretanto, antes de entrarem na área experimental, esses animais passaram por um potreiro "escola" nas mesmas condições de manejo dos potreiros utilizados na área experimental. Os períodos de descanso foram definidos com a intenção de determinar quando houvesse máximo acúmulo de folhas vivas, conforme determinado por Martins et al. (2005), que verificaram, para o milheto, número máximo de 5,5 folhas vivas por perfilho, de forma que, naquele instante, aproximadamente três folhas estavam expandidas. Esses resultados sugerem que, se a intenção for trabalhar com pastejo rotativo, o tratamento central deve ser o período de descanso necessário para que três novas folhas fiquem expandidas, assim, apenas folhas vivas seriam colhidas. Desse modo, foram testados períodos de descanso para expansão, em média, de 1,5 a 2; 2,5 a 3; e 3,5 a 4 novas folhas por perfilho. Foi mantido, para os três períodos de descanso resíduo semelhante de lâminas verdes de $743 \mathrm{~kg} / \mathrm{ha}$ de MS, o qual foi mensurado a partir de quatro amostras da pastagem por unidade experimental, cortadas no nível do solo, dentro de um quadrado de $0,25 \mathrm{~m}^{2}$. O delineamento experimental foi completamente ao acaso, com quatro repetições (potreiros).

As características estruturais foram avaliadas pela técnica de "perfilhos marcados", conforme metodologia detalhada por Carrère et al. (1997). Em cada potreiro, foram marcados com fio colorido dez perfilhos representativos da pastagem. A cada avaliação, foi medido, com régua graduada, o comprimento da fração verde das lâminas foliares expandidas (aparecimento da lígula) ou emergentes. O comprimento das lâminas expandidas foi medido a partir de suas respectivas lígulas, enquanto o das lâminas emergentes foi medido a partir da penúltima lígula visível. As avaliações foram realizadas duas vezes por semana, durante os períodos de descanso. Depois de cada processo de desfolha, foram marcados novos perfilhos para integração de novos indivíduos, visando manter a representatividade da população. Utilizando-se estas medições, foram avaliadas as características estruturais: número de folhas vivas/ perfilho, comprimento da lâmina foliar, relação lâmina/ bainha e colmo $(\mathrm{L} / \mathrm{B}+\mathrm{C})$, densidade de perfilhos basilares e densidade de perfilhos aéreos. As medições de relação $\mathrm{L} / \mathrm{B}+\mathrm{C}$ foram realizadas pela separação botânica de quatro amostras da pastagem/unidade experimental, cortadas no nível do solo dentro de quadrados com $0,25 \mathrm{~m}^{2}$ momentos antes da entrada dos animais na área. A densidade de perfilhos, por sua vez, foi obtida pela contagem do número de perfilhos in loco em quatro repetições/unidade experimental com área de $20 \mathrm{~cm} \times 50 \mathrm{~cm}$. As condições meteorológicas durante o período experimental (dados coletados no local do experimento) foram bastante favoráveis ao crescimento da forrageira, com precipitação pluviométrica 
total de 670,7 mm e temperaturas máxima e mínima de 25,5 e $20,2^{\circ} \mathrm{C}$, respectivamente. Os dados foram submetidos à análise de variância e, posteriormente, comparados pelo teste DMS Fischer $(\mathrm{P}<0,05)$, realizando-se a análise de regressão polinomial para descrição das variáveis no tempo com o mesmo nível de significância citado anteriormente.

\section{Resultados e Discussão}

Os três períodos de descanso, ou seja, o tempo necessário para formação de 1,5 a 2; 2,5 a 3; e 3,5 a 4 novas folhas expandidas corresponderam, respectivamente, a períodos de 12,1; 18,6 e 22 dias de descanso (Tabela 1).

Os períodos de descanso influenciaram o número de folhas vivas expandidas, que foi mais alto no menor período de descanso. Este resultado provavelmente se deve ao menor número de folhas remanescentes do pastejo que entraram em processo de senescência ao longo do período de descanso. No período de descanso de 1,5 a 2 folhas, logo após o pastejo, havia em média 3,82 folhas vivas expandidas e destas, ao final do período de descanso, 1,42 estava em processo de senescência. $O$ restante destas folhas que se mantiveram vivas $(2,4)$, somado à formação de 1,7 nova folha expandida totalizou 4,1 folhas vivas expandidas. $\mathrm{O}$ maior número de folhas vivas expandidas confere à pastagem maior capacidade fotossintética, pois é neste estágio em que ocorre fotossíntese máxima. Os assimilados produzidos nestas folhas são utilizados não apenas para sua própria manutenção, mas também para atender às necessidades do meristema apical, do sistema radicular e das folhas emergentes (Pedreira et al., 2001). Por esta razão, assim como o maior número de folhas vivas expandidas, maior número de folhas vivas emergentes também foi verificado no menor período de descanso.

De modo geral, os valores observados neste trabalho foram semelhantes aos encontrados por Martins et al. (2005) em estudo com milheto. No entanto, trabalhos com outras espécies resultam em valores, na sua grande maioria, próximos a 1,0 folha viva emergente e raramente superiores a duas folhas vivas emergentes (Pontes et al., 2003; Fagundes et al., 2006). Ressalta-se que, nas avaliações iniciais, o número foi superior a três em todos os períodos de descanso (variando entre 3,5 e 3,3 folhas vivas emergentes). Entretanto, ao longo do período experimental, esses valores diminuíram e foram descritos por equações lineares negativas (Figura 1).

Todavia, apesar de o período de descanso de 3,5 a 4 folhas ter apresentado coeficiente A semelhante ao dos demais períodos de descanso, a declividade foi maior, pois, com o avanço das gerações de perfilhos, provavelmente, ocorreu redução progressiva no número de fitômeros. Como nesse período de descanso era necessária a formação de pelo menos 3,5 novas folhas expandidas, após este evento restavam cada vez menos folhas emergentes com o transcorrer do período experimental.

Os maiores números de folhas expandidas e de folhas emergentes determinaram para o período de descanso de 1,5 a 2 folhas o maior número total de folhas vivas (Tabela 1). Tendências semelhantes foram verificadas por Martuscello et al. (2005) com Brachiaria brizantha cv. Xaraés e Silveira \& Monteiro (2007) com Panicum maximum cv. Tanzânia, que também observaram maior número de folhas vivas no menor período de descanso e maior número total

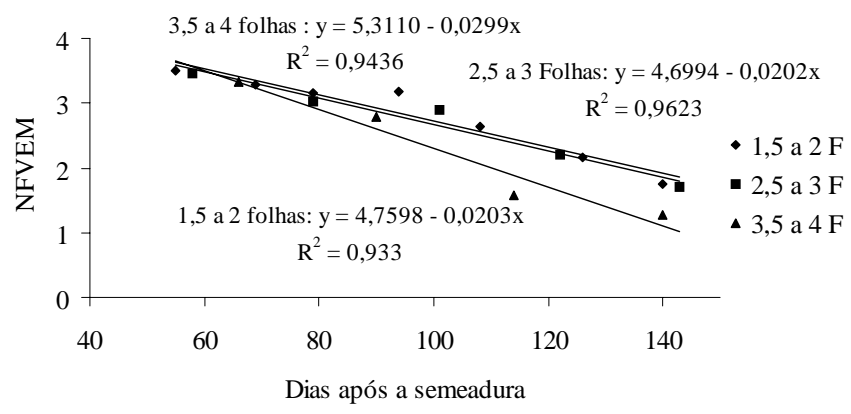

Figura 1 - Relação entre o número de folhas vivas emergentes (FVEM) e dias após a semeadura.

Tabela 1 - Duração dos períodos de descanso e características das folhas de milheto nos três períodos de descanso

\begin{tabular}{lccc}
\hline & \multicolumn{3}{c}{ Período de descanso } \\
\cline { 2 - 4 } & $1,5 \mathrm{a} 2$ folhas & 2,5 a 3 folhas & $3,5 \mathrm{a} 4$ folhas \\
\hline Duração do período de descanso (dias) & 12,1 & 18,6 & 22,0 \\
Folhas expandidas no período de descanso & $1,7 \mathrm{c}$ & $3,6 \mathrm{a}$ \\
Folhas vivas expandidas logo após o pastejo & $3,8 \mathrm{a}$ & $2,8 \mathrm{~b}$ & $2,8 \mathrm{~b}$ \\
Folhas senescentes & $1,42 \mathrm{~b}$ & $3,4 \mathrm{a}$ & $2,65 \mathrm{a}$ \\
Folhas vivas expandidas & $4,15 \mathrm{a}$ & $2,52 \mathrm{a}$ & $3,78 \mathrm{~b}$ \\
Folhas vivas emergentes & $2,81 \mathrm{a}$ & $3,68 \mathrm{~b}$ & $2,24 \mathrm{~b}$ \\
Total de folhas vivas & $6,97 \mathrm{a}$ & $2,66 \mathrm{a}$ & $6,02 \mathrm{~b}$ \\
\hline
\end{tabular}

Valores com letras iguais na mesma coluna não diferem pelo teste DMS a 5\% de significância. 
de folhas vivas com o aumento do número de cortes, respectivamente.

O maior número total de folhas vivas obtido no período de descanso de 1,5 a 2 folhas também pode ser explicado pela forte correlação desta característica estrutural com as características morfogênicas de tempo de vida da folha e taxa de surgimento de folhas, uma vez que, com maior taxa de surgimento e maior tempo de sobrevivência, maior número de folhas se mantém vivas/perfilho (Cauduro et al., 2006). Como o total de folhas vivas foi semelhante nos três períodos de descanso, a taxa de surgimento de folhas foi determinante, pois o maior valor para esta variável foi observado no período de descanso de 1,5 a 2 folhas $(0,158$ folhas/dia). Esse elevado número de folhas vivas é uma característica estrutural desejável, pois indica acentuada capacidade da pastagem em armazenar forragem verde. Essa característica confere maior potencial para assimilação de carbono, captura de energia e capacidade de retenção de reservas, o que provavelmente resultará em rebrote mais vigoroso (Martuscello et al., 2006).

No decorrer do período experimental, o número de folhas vivas decresceu linearmente nos três períodos de descanso (Figura 2). Inicialmente, em virtude da menor senescência das lâminas residuais e da formação de 3,5 a 4

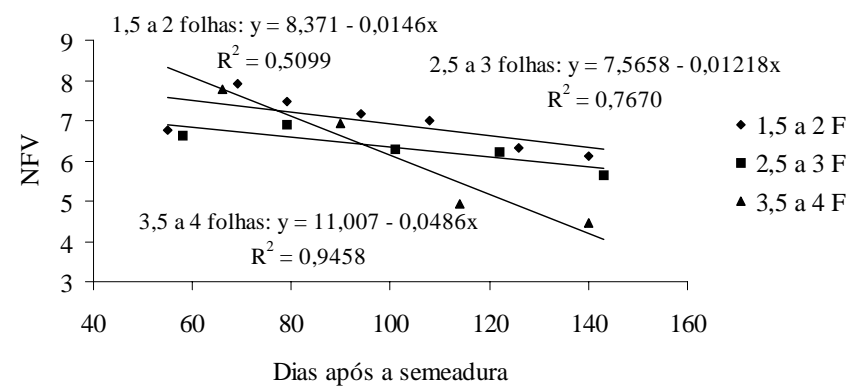

Figura 2 - Relação entre o número de folhas vivas e dias após a semeadura. novas folhas expandidas, foi verificado elevado número de folhas vivas ( 8,36 folhas/perfilho) no maior período de descanso. Entretanto, nas avaliações seguintes, esse valor decresceu com declividade superior aos demais períodos de descanso, principalmente em virtude da redução no número de folhas emergentes.

Martins et al. (2005) estudaram as características estruturais de milheto e verificaram número médio de folhas vivas um pouco inferior (5,5 NFV) aos deste trabalho (Tabela 1). Os resultados observados nesta pesquisa podem indicar o excelente potencial desta espécie forrageira em acumular forragem verde, pois são semelhantes ou superiores aos encontrados para a maioria das principais espécies forrageiras tropicais utilizadas no Brasil. Martuscello et al. (2005), Martuscello et al. (2006), Pauciullo et al. (2003) e Alexandrino et al. (2004), em pesquisa com Braquiária brizantha cv. Xaraés, Panicum maximum cv. Massai, Pennisetum purpureum e Brachiaria brizantha cv. Marandu, respectivamente, encontraram valores entre 5,1 e 5,77 folhas vivas. Valores mais próximos foram encontrados para B. brizantha cv. Marandu (Alexandrino et al., 2004), B. decumbens (Corsi et al., 1994) e P. maximum cv. Vencedor (Gomide \& Gomide, 2000), enquanto valores superiores foram verificados apenas para Pennisetum purpureum cv. Mott, que apresentou número máximo de 11 folhas vivas (Setelich, 1999).

Assim como o total de folhas vivas, o comprimento final da lâmina também foi influenciado pelos períodos de descanso (Tabela 2). O menor comprimento final da lâmina registrado no menor período de descanso provavelmente esteve associado ao menor tempo que estas folhas tiveram para crescer (Tabela 1). Conforme descrito por Pontes et al. (2003), o comprimento final da lâmina também está associado à altura da bainha. Esses autores verificaram maior comprimento final da lâmina no período de descanso com maior altura da bainha e atribuíram este resultado ao maior percurso percorrido pela lâmina no pseudocolmo até

Tabela 2 - Comprimento final da lâmina, relação lâmina/bainha e colmo, densidade de perfilhos basilares, aéreos e totais nos três períodos de descanso

\begin{tabular}{|c|c|c|c|}
\hline & \multicolumn{3}{|c|}{ Período de descanso } \\
\hline & 1,5 a 2 folhas & 2,5 a 3 folhas & 3,5 a 4 folhas \\
\hline Comprimento final da lâmina $(\mathrm{cm})$ & $22,73 b$ & $27,43 \mathrm{a}$ & $30,17 \mathrm{a}$ \\
\hline "LV (cm) & $158,50 \mathrm{a}$ & $173,64 \mathrm{a}$ & $181,77 \mathrm{a}$ \\
\hline Relação lâmina/bainha+colmo & $0,92 \mathrm{a}$ & $0,68 b$ & $0,48 \mathrm{c}$ \\
\hline \multicolumn{4}{|l|}{ Perfilhos $/ \mathrm{m}^{2}$} \\
\hline Basilares & $441,61 \mathrm{a}$ & $382,25 b$ & $360,78 b$ \\
\hline Aéreos & $75,98 b$ & $167,00 \mathrm{a}$ & $185,62 \mathrm{a}$ \\
\hline Total & $517,59 \mathrm{a}$ & $549,25 \mathrm{a}$ & $546,40 \mathrm{a}$ \\
\hline
\end{tabular}

"LV = comprimento da soma de todas lâminas vivas/perfilho.

Valores com letras iguais na mesma coluna não diferem pelo teste de DMS a 5\% de significância. 
sua emergência completa. As maiores alturas de lígula verificadas nos períodos de descanso de 2,5 a $3(62,10 \mathrm{~cm})$ e de 3,5 a 4 folhas $(87,34 \mathrm{~cm})$ justificam os maiores comprimentos finais de lâminas obtidos nesses períodos de descanso. O menor comprimento final de lâmina no menor período de descanso também pode ser explicado pelo processo de adaptação da planta à maior freqüência e intensidade de desfolha, pela sua plasticidade fenotípica relatada na literatura, como estratégia morfológica de escape ao pastejo (Lemaire \& Chapman, 1996). Esse mecanismo de co-evolução da planta durante o pastejo foi verificado por Castro (2002) em pastagem de milheto em diversas alturas sob pastejo contínuo de ovinos. Esse autor obteve menores comprimentos finais de lâmina nas menores alturas da pastagem: na maior altura $(40 \mathrm{~cm}-\mathrm{CFL}=22,5 \mathrm{~cm})$, o comprimento final de lâmina foi muito semelhante ao encontrado no período de descanso de 1,5 a 2 folhas.

No decorrer do período experimental, houve decréscimos lineares no comprimento final de lâmina em todos os períodos de descanso (Figura 3). Nas primeiras avaliações, foram verificados valores semelhantes e mais elevados para os períodos de descanso de 2,5 a 3 folhas $(34,84 \mathrm{~cm})$ e de 3,5 a 4 folhas $(36,1 \mathrm{~cm})$ em relação ao de 1,5 a 2 folhas $(25,86 \mathrm{~cm})$. Por outro lado, nas avaliações finais, foram verificados comprimentos finais de lâminas bastante semelhantes nos três períodos de pastejo, o que resultou no aumento do coeficiente de inclinação com o aumento do período de descanso.

Os maiores valores do comprimento final de lâmina nas primeiras avaliações podem ser explicados pelo predomínio de folhas em níveis de inserção intermediários no dossel da pastagem. Segundo Gomide \& Gomide (2000), nesse nível de inserção, as folhas têm maior trajeto a percorrer dentro do pseudocolmo, resultando em maior tamanho de folhas ao longo do ciclo de crescimento. Posteriormente, com o progressivo alongamento dos entrenós e a elevação do meristema apical, a distância percorrida pela folha emergente no interior do pseudocolmo foi se reduzindo e, conseqüentemente, seu tamanho final também se reduziu.

Embora o comprimento final da lâmina tenha sido afetado pelos períodos de descanso, o comprimento de todas as lâminas vivas somadas/perfilho (LV) não diferiu entre os períodos de descanso (Tabela 2). Essa semelhança pode ser atribuída a características adaptativas da planta, pois os períodos de descanso com maior comprimento final da lâmina, no entanto, apresentaram menor número de lâminas foliares. Este evento foi relatado por Lemaire \& Agnusdei (1999), que afirmaram haver forte relação destas variáveis com a velocidade de surgimento da folha. Assim, o manejo de desfolha que permitiu maior velocidade de surgimento da folha, como verificado no período de descanso de 1,5 a 2 folhas $(6,38)$, ocasionou maior número de folhas, porém com menor comprimento.

Ao longo do período experimental, o LV diminuiu linearmente entre os períodos de descanso. Tanto a redução do comprimento final da lâmina como a redução do número total de folhas/perfilho determinaram reduções do LV de 44,54 e $72 \%$ para os períodos de descanso de 1,5 a 2; de 2,5 a 3 e de 3,5 a 4 novas folhas expandidas, respectivamente, considerando o primeiro em relação ao último ciclo de pastejo (Figura 4).

A densidade de perfilhos basilares foi influenciada pelos períodos de descanso e foi maior no menor período de descanso (aproximadamente 2 semanas). Após as duas semanas (períodos de descanso de 2,5 a 3 e de 3,5 a 4 novas folhas), a evolução da área foliar impede a chegada de luz até a base da touceira para que ocorra a ativação das gemas axilares (Barbosa et al., 2002). Nesta ocasião, ocorrem alteração no espectro solar transmitido pelo interior do dossel até a superfície do solo e sombreamento mútuo das folhas. Com o dossel fechado, são alteradas a quantidade e a qualidade de luz, influenciando a luminosidade detectada pelo fitocromo. Desse modo, para a melhoria do ambiente luminoso, ocorre o alongamento dos entrenós, inibindo o

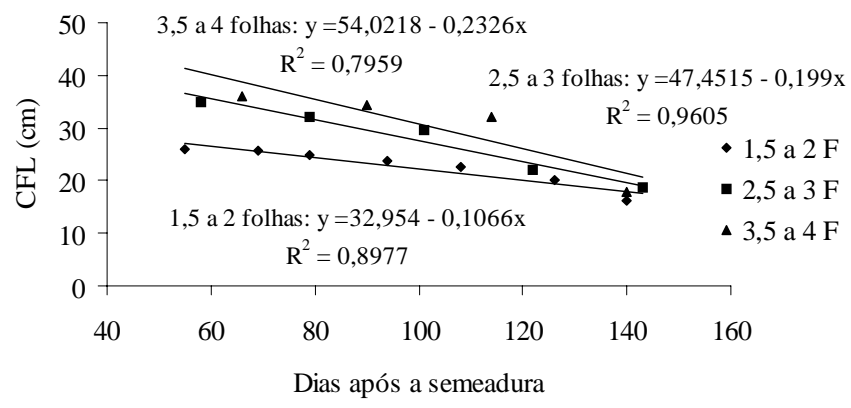

Figura 3 - Relação entre o comprimento final da lâmina e dias após a semeadura.

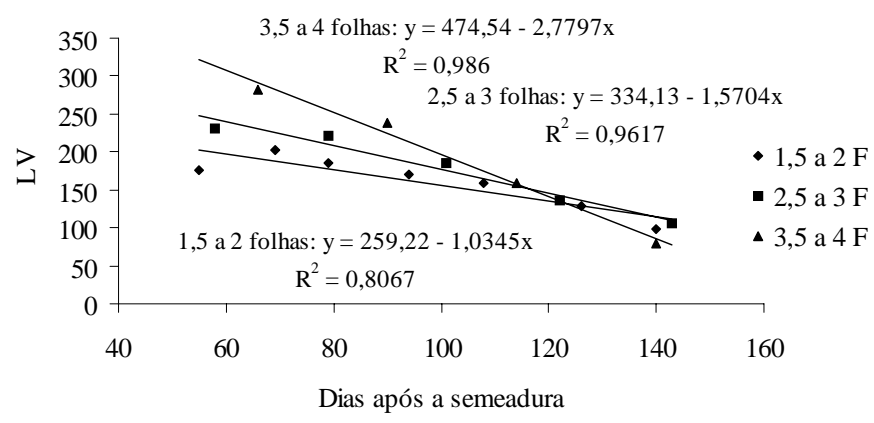

Figura 4 - Relação entre o comprimento de todas as lâminas vivas somadas (LV)/perfilho e dias após a semeadura. 
perfilhamento (Candido et al., 2006). Essas observações poderiam explicar a maior altura e a menor densidade de perfilhos basilares com o aumento do período de descanso (alturas da pastagem no momento pré-pastejo-PD 1,5 a 2 folhas $=55 \mathrm{~cm}$; PD 2,5 a 3 folhas $=82 \mathrm{~cm}$ e PD 3,5 a 4 folhas $=106 \mathrm{~cm}$ ).

A densidade de perfilhos basilares encontrada neste trabalho é semelhante à obtida por Castro (2002) na mesma espécie, porém com pastejo contínuo de ovinos. Esses resultados comprovam a excelente capacidade de perfilhamento do milheto, pois estes valores são semelhantes aos obtidos para $P$. maximum cv. Tanzânia (Cândido et al., 2006) e superiores aos verificados para $P$. maximum cv. Mombaça (Santos et al., 2004), importantes cultivares tropicais melhorados para esse fim.

Durante o ciclo de crescimento, foi verificado aumento da densidade de perfilhos basilares durante o estágio vegetativo (Figura 5). A última adubação em cobertura, próxima aos 80 dias após a semeadura, contribuiu para maior ativação das gemas axilares e maior taxa de aparecimento de folhas neste estágio (Garcez Neto et al., 2002). Assim, com o maior espaçamento entre perfilhos e a menor competição por nutrientes e por luz, a taxa de perfilhamento ficou muito próxima da taxa de surgimento de folhas, momento conhecido na literatura como site feeling (Davis, 1974). A partir de então, verificou-se estabilização da densidade de perfilhos basilares relatada como site usage (Skinner \& Nelson, 1992), onde o dossel se tornou mais denso e aumentou a competição por luz e por nutrientes, impedindo novos acréscimos na densidade de perfilhos. Posteriormente, com o avanço do estágio reprodutivo, as inversões de assimilados foram direcionadas cada vez mais para a produção de semente ocasionando importante diminuição no perfilhamento.

Na pastagem de milheto, o perfilho aéreo se desenvolve por alguma deficiência na panícula dos perfilhos principais

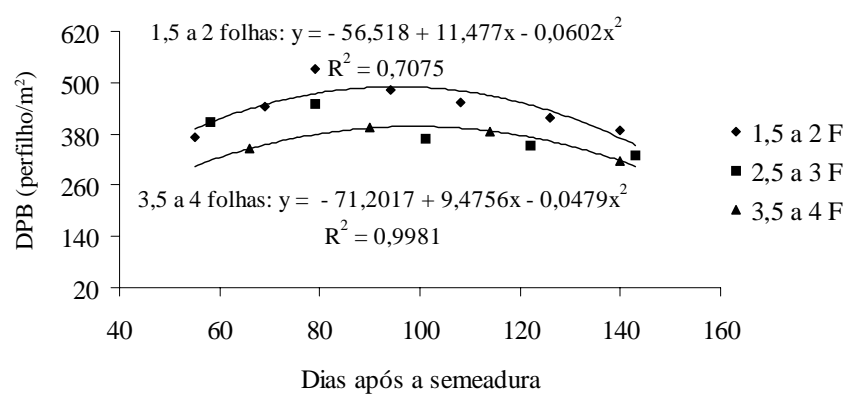

Figura 5 - Relação entre a densidade de perfilhos basilares (DPB) e dias após a semeadura.
(Durães et al., 2003). Nesse sentido, a maior densidade de perfilhos aéreos (DPA) foi verificada nos maiores períodos de descanso (de 2,5 a 3; e de 3,5 a 4 folhas), nos quais houve florescimento, iniciação e desenvolvimento da panícula.

A evolução do perfilhamento aéreo ao longo do tempo foi mais bem descrita por equações lineares positivas para nos três períodos de descanso (Figura 6). Esses desempenhos estão de acordo com o observado por Barbosa et al. (2002), que relataram aumento das chances do perfilhamento aéreo com o avanço da idade da planta. $\mathrm{O}$ aumento da densidade de perfilhos aéreos no transcorrer do ciclo de crescimento da pastagem também pode ser explicado pela maior remoção de meristemas apicais pela ação do pastejo, portanto, há ativação de gemas axilares abaixo da referida decapitação.

A maior densidade de perfilhos aéreos (310 perfilhos $/ \mathrm{m}^{2}$ ) ao final do experimento no período de descanso de 3,5 a 4 folhas determinou o maior coeficiente de declividade neste período de descanso.

Com os aumentos inversamente proporcionais da densidade de perfilhos basais e da densidade de perfilhos aéreos, a densidade total de perfilhos foi semelhante nos três períodos de descanso (média $=537,74$ perfilhos $/ \mathrm{m}^{2}$ ).

Apesar do acréscimo do perfilhamento aéreo com o aumento do período de descanso, a maior densidade e a menor altura dos perfilhos basilares no período de descanso de 1,5 a 2 folhas foram determinantes para que neste tratamento fosse verificada a maior relação lâmina/ bainha somada ao colmo ( $\mathrm{L} / \mathrm{B}+\mathrm{C})$, a qual decresceu com o aumento do período de descanso (Tabela 2). Essa tendência de estreitamento da relação $\mathrm{L} / \mathrm{B}+\mathrm{C}$ com o aumento do período de descanso também foi verificada por Cândido et al. (2005) e Santos et al. (1999), em P. maximum cv. Mombaça. Em estudos com milheto, são relatados valores de L/B+C semelhantes: enquanto Scaravelli et al. (2007) verificaram média levemente superior $(\mathrm{L} / \mathrm{B}+\mathrm{C}=1,16)$ à do menor período de descanso, Castro (2002) encontrou valores

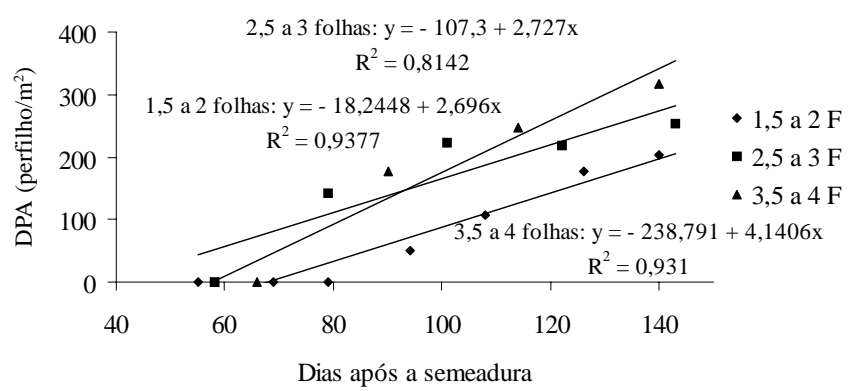

Figura 6 - Relação entre a densidade de perfilhos aéreos (DPA) e dias após a semeadura. 


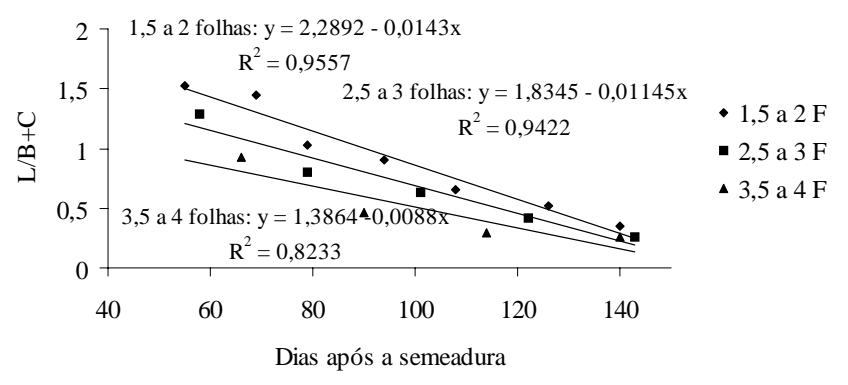

Figura 7 - Relação entre a relação lâmina/bainha mais colmo $(\mathrm{L} / \mathrm{B}+\mathrm{C})$ e dias após a semeadura.

um pouco inferiores aos do maior período de descanso estudado.

Ao longo do período experimental, essa relação $(\mathrm{L} / \mathrm{B}+\mathrm{C})$ decresceu linearmente (Figura 7). Os maiores valores foram de 1,53 e 1,29 para período de descanso de 1,5 a 2 e de 2,5 a 3 folhas, respectivamente; enquanto, para o maior período de descanso, o valor máximo foi inferior a 1,0. Entretanto, ao final do período experimental, os valores foram semelhantes nos três períodos de descanso, o que determinou o maior coeficiente de declividade com a redução do período de descanso.

Esta maior participação de colmos em relação à de lâminas propiciada pelo maior período de descanso durante todo o ciclo de crescimento da pastagem determinou características estruturais indesejáveis sob o ponto de vista forrageiro. Os maiores espaçamentos entre as folhas e a imposição física dos colmos ao animal ocasionaram, provavelmente, menor coleta de forragem por bocado e, conseqüentemente, maior gasto de energia na busca da dieta.

\section{Conclusões}

Quando utilizado sob pastejo rotativo, as características estruturais do milheto são afetadas pelo período de descanso. Para o manejo adequado, é necessário período de descanso suficiente para a expansão completa de 1,5 a 2,0 novas folhas.

\section{Literatura Citada}

ALEXANDRINO, E.; NASCIMENTO JR., D.; MOSQUIM, P.R et al. Características morfogênicas e estruturais na rebrotação da Brachiaria brizantha cv. Marandu submetida a três doses de nitrogênio. Revista Brasileira de Zootecnia, v.33, n.6, p.1372-1379, 2004.

BARBOSA, R.A.; NASCIMENTO JR, D.; EUCLIDES, V.P.B. et al. Características morfogênicas e acúmulo de forragem do capimtanzânia (Panicum maximum Jacq. cv. Tanzânia) em dois resíduos forrageiros pós-pastejo. Revista Brasileira de Zootecnia, v.31, n.2, p.583-593, 2002.

CANDIDO, M.J.D.; GOMIDE, C.A.M.; ALEXANDRINO, E. et al. Morfofisiologia do dossel de Panicum maximum cv. Mombaça sob lotação intermitente com três períodos de descanso. Revista Brasileira de Zootecnia, v.34, n.2, p.406-415, 2005.

CANDIDO, M.J.D.; SILVA, R.G.; NEIVA, J.N.M. et al. Fluxo de biomassa de capim-tanzânia pastejado por ovinos sob três períodos de descanso. Revista Brasileira de Zootecnia, v.35, n.6, p.2234-2242, 2006.

CARRĖRE, P.; LOUAULT, F.; SOUSSANA, J.F. Tissue turnover within grass-clover mixed swards grazed by sheep. Methodology for calculating growth, senescence and intake fluxes. Journal of Applied Ecology, v.34, p.333-348, 1997.

CASTRO, C.C.R. Relações planta-animal em pastagem de milheto (Pennisetun americanum (L.) Leeke.) manejada em diferentes alturas com ovinos. 2002. 185f. Dissertação (Mestrado em Zootecnia) - Faculdade de Agronomia, Universidade Federal do Rio Grande do Sul, Porto Alegre, 2002.

CAUDURO, G.F.; CARVALHO, P.C.F.; BARBOSA, C.M.P. et al. Variáveis morfogênicas e estruturais de azevém anual (Lolium multiflorum Lam.) manejado sob diferentes intensidades e métodos de pastejo. Revista Brasileira de Zootecnia, v.35, n.4, p.1298-1307, 2006.

CAUDURO, G.F.; CARVALHO, P.C.F.; BARBOSA, C.M.P. et al. Fluxo de biomassa aérea em azevém anual manejado sob duas intensidades e dois métodos de pastejo. Revista Brasileira de Zootecnia, v.36, n.2, p.282-290, 2007.

CORSI, M.; BALSALOBRE, M.A.A.; SANTOS, P.M. et al. Bases para o estabelecimento do manejo de pastagens de braquiária. In: SIMPÓSIO SOBRE MANEJO DE PASTAGENS, 1994, Piracicaba. Anais... Piracicaba: Escola Superior de Agricultura Luiz de Queiroz, 1994. p.249-266.

CUNHA, N.G.; SILVEIRA, R.J.C.; SEVERO, C.R.S. et al. Estudos dos solos do município de Piratini. Pelotas: EMBRAPACPACT, 1998. 91p. (Documentos, 26).

DAVIES, A. Leaf tissue remaining after cutting and regrowth in perennial ryegrass. Journal of Agricultural Science, v.82, p.165-172, 1974

DURÃES, F.O.M.; MAGALHÃES, P.C.; SANTOS, F.G. Fisiologia da planta de milheto. Sete Lagoas: Embrapa Milho e Sorgo, 2003. 65p. (Circular Técnica, 28).

FAGUNDES, J.L.; FONSECA, D.M.; MISTURA, C. et al. Características morfogênicas e estruturais do capim-braquiária em pastagem adubada com nitrogênio avaliadas nas quatro estações do ano. Revista Brasileira de Zootecnia, v.35, n.1, p.21-29, 2006.

GARCEZ NETO, A.F.; NASCIMENTO JR. D.; REGAZZI, A.J. et al. Respostas morfogênicas e estruturais de Panicum maximum cv. Mombaça sob diferentes níveis de adubação nitrogenada e alturas de corte. Revista Brasileira de Zootecnia, v.31, n.5, p.1890-1900, 2002.

GOMIDE, C.A.M.; GOMIDE, J.A. Morfogênese de cultivares de Panicum maximum Jacq. Revista Brasileira de Zootecnia, v.29, n.2, p.341-348, 2000.

INGRID, H.; MOOJEN, E.L. Potencial produtivo, alterações da estrutura e qualidade da pastagem de milheto submetida a diferentes níveis de nitrogênio. Revista Brasileira de Zootecnia, v.31, n.2, p.875-882, 2002.

LEMAIRE, G.; CHAPMAN, D. Tissue fluxes in grazing plant communities. In: HODGSON, J.; ILlIUS, A.W. (Eds.). The Ecology and management of grazing systems. Wallingford: CAB International, 1996. p.3-36.

LEMAIRE, G.; AGNUSDEI, M. Leaf tissue turn over and efficiency of herbage utilization. In: SIMPÓSIO INTERNACIONAL "GRASSLAND ECOPHYSIOLOGY AND ECOLOGY", 1., 1999, Curitiba. Anais... Curitiba: Universidade Federal do Paraná, 1999. p.165-183. 
MARTINS, C.E.N.; QUADROS, F.L.F.; BANDINELLI, D.G. Variáveis morfogênicas de milheto (Pennisetum americanum) mantido em duas alturas de pastejo. Ciência Rural, v.35, n.1, p.174-180, 2005.

MARTUSCELLO, J.A.; FONSECA, D.M.; NASCIMENTO JR., D. et al. Características morfogênicas e estruturais do capim-xaraés submetido a adubação nitrogenada e desfolhação. Revista Brasileira de Zootecnia, v.34, n.5, p.1475-1482, 2005

MARTUSCELLO, J.A.; FONSECA, D.M.; NASCIMENTO JR., D et al. Características morfogênicas e estruturais do capim-massai submetido a adubação nitrogenada e desfolhação. Revista Brasileira de Zootecnia, v.35, n.3, p.665-671, 2006.

MOOJEN, E.L.; RESTLE, J.; LUPATINI, G.C. et al. Produção animal em pastagem de milheto sob diferentes níveis de nitrogênio. Pesquisa Agropecuária Brasileira, v.34, n.11, p.2145-2149, 1999.

PACIULlO, D.S.C.; DERESZ, F.; AROEIRA, L.J.M. et al. Morfogênese e acúmulo de biomassa foliar em pastagem de capim-elefante avaliada em diferentes épocas do ano. Pesquisa Agropecuária Brasileira, v.38, n.7, p.881-887, 2003.

PEDREIRA, C.G.S.; MELLO, A.C.L.; OTANI, L. O processo de produção de forragem em pastagens. In: REUNIÃO ANUAL DA SOCIEDADE BRASILEIRA DE ZOOTECNIA, 38., 2001, Piracicaba. Anais... Piracicaba: Sociedade Brasileira de Zootecnia, 2001. p.772-807.

PONTES, L.S.; NABINGER, C.; CARVALHO, P.C.F. et al. Variáveis morfogênicas e estruturais de azevém anual (Lolium multiflorum Lam.) manejado em diferentes alturas. Revista Brasileira de Zootecnia, v.32, n.4, p.814-820, 2003.
SANTOS, P.M.; CORSI, M.; BALSALOBRE, M.A.A. Efeito da frequiência de pastejo e da época do ano sobre a produção e a qualidade em Panicum maximum cvs. Tanzânia e Mombaça. Revista Brasileira de Zootecnia, v.28, n.2, p.244-249, 1999.

SANTOS, P.M.; BALSALOBRE, M.A.A.; CORSI, M. Característica morfogênica e taxa de acúmulo de forragem do capim mombaça submetido a três intervalos de pastejo. Revista Brasileira de Zootecnia, v.33, n.4, p.843-851, 2004.

SCARAVELLI, L.F.B.; PEREIRA, L.E.T.; OLIVO, C.J. et al. Produção e qualidade de pastagens de Coastcross-1 e milheto utilizadas com vacas leiteiras. Ciência Rural, v.37, n.3, p. 841-846, 2007.

SETELICH, E.A. Resposta à adubação nitrogenada de capimelefante anão (Pennisetum purpureum Schum. cv. MOTT) sob pastejo no alto vale do Itajaí, Santa Catarina. 1999. 132f. Tese (Doutorado em Zootecnia) - Faculdade de Agronomia, Universidade Federal do Rio Grande do Sul, Porto Alegre, 1999.

SILVEIRA, C.P.; MONTEIRO, F.A. Morfogênese e produção de biomassa do capim-tanzânia adubado com nitrogênio e cálcio. Revista Brasileira de Zootecnia, v.36, n.2, p.335-342, 2007.

SKINNER, R.H.; NELSON, C.J. Estimation of potential tiller production and site usage during tall fescue canopy development. Annals of Botany, v.70, p.493-499, 1992.

SOCIEDADE BRASILEIRA DE CIÊNCIA DO SOLO. COMISSÃO DE QUímICA E FERTILIDADE DO SOLO. Manual de adubação e de calagem para os estados do Rio Grande do Sul e de Santa Catarina. 10.ed. Porto Alegre: Sociedade Brasileira de Ciência do Solo. Comissão de Química e Fertilidade do Solo, 2004. 400p. 